\title{
HAEMODYNAMIC AND BIOCHEMICAL VARIABLES AFTER INDUCTION OF ANAESTHESIA WITH FENTANYL AND NITROUS OXIDE IN PATIENTS UNDERGOING CORONARY ARTERY BY-PASS SURGERY
}

\author{
O. Prakash, P.D. Verdouw, J.W. de Jong, S.H. MeiJ, S.G. van der Borden, K.M. Dhasmana \\ AND P.R. SAXENA
}

\begin{abstract}
The effects on the haemodynamic and biochemical parameters of three different anaesthetic induction regimes, namely fentanyl $\left(4.1 \mu \mathrm{g} \cdot \mathrm{kg}^{-1}\right.$ or $\left.15 \mu \mathrm{g} \cdot \mathrm{kg}^{-1}\right)$ plus 60 per cent nitrous oxide with oxygen and fentanyl $15 \mu \mathrm{g} \cdot \mathrm{kg}^{-1}$ plus 60 per cent nitrogen with oxygen, were studied in patients undergoing coronary artery surgery. Fentanyl $15 \mu \mathrm{g} \cdot \mathrm{kg}^{-1}$ with nitrous oxide and oxygen produced simultaneous reductions in oxygen uptake, cardiac index and left ventricular stroke work with an unaltered oxygen extraction. Diastolic blood pressure (an index of coronary artery perfusion) was only slightly reduced, and there were no changes in arterial lactate, glucose and free fatty acids. The lower dose of fentanyl $\left(4.1 \mu \mathrm{g} \cdot \mathrm{kg}^{-1}\right)$ with nitrous oxide produced no haemodynamic changes but decreased the oxygen uptake and extraction. The patients recciving fentanyl $15 \mu \mathrm{g} \cdot \mathrm{kg}^{-1}$ with nitrogen and oxygen showed increases in heart rate, blood pressure, cardiac index and left ventricular stroke work, together with a significant fall in oxygen extraction. Moreover, in the patients who received fentanyl $4.1 \mu \mathrm{g} \cdot \mathrm{kg}^{-1}$ with nitrous oxide and oxygen and fentanyl $15 \mu \mathrm{g} \cdot \mathrm{kg}^{-1}$ with nitrogen and oxygen there were significant increases in blood lactate, glucose and free fatty acids, indicating increased sympathetic activity. We conclude that fentanyl $15 \mu \mathrm{g} \cdot \mathrm{kg}^{-1}$, together with 60 per cent nitrous oxide with oxygen provides a satisfactory haemodynamic and biochemical state during induction of anaesthesia in patients with myocardial function prejudiced by coronary artery insufficiency.
\end{abstract}

FENTANYL IS WIDELY USED as a narcotic analgesic for cardiovascular anaesthesia. The drug is usually given in combination with other anaesthetic agents since, when given alone, fentanyl can enhance the activity of the adrenergic nervous system. ${ }^{1}$ However, recent studies have shown that high doses of fentanyl, up to $160 \mu \mathrm{g} \cdot \mathrm{kg}^{-1}$, neither depress myocardial performance nor increase whole body oxygen consumption in $\operatorname{dogs}^{2}$ and produce adequate anaesthesia in man..$^{3.4}$ On the other hand, Verdouw, de Jong, Merin and Schamhardt ${ }^{5}$ have reported elevated arterial free fatty acid (FFA) levels in swine given fentanyl $50 \mu \mathrm{g} \cdot \mathrm{kg}^{-1}$; this might be considered undesirable in view of the evidence that free fatty acid utilization by the heart may be harmful during ischaemia, especially when accompanied by elevated sympathetic activity. ${ }^{6}$

O. Prakash, M.D., P.D. Verdouw, Ph.D., J.W. de Jong, Ph.D., S.H. Meij, M.Sc., S.G. van der Borden, B.Sc., K.M. Dhasmana, M.D., P.R. Saxena, M.D. Department of Anaesthesia and Cardiovascular Research, Thoraxcentrum, University Hospital and Department of Pharmacology, Erasmus University Rotterdam, P.O. Box 1738, Rotterdam, The Netherlands.

Correspondence: O. Prakash, Consultant Anaesthetist, Thoraxcentrum, Eras mus University, P.O. Box 1738, 3000 DR Rotterdam, The Netherlands.
In the present study, we have examined the haemodynamic and metabolic variables in patients during routine induction of anaesthesia for coronary artery by-pass surgery. The effect on these variables of fentanyl in combination with nitrous oxide or nitrogen and oxygen has been studied against a background of neuromuscular blockade with pancuronium, to evaluate the cardiovascular suitability of the drug in patients with coronary artery disease.

\section{METHODS}

Seventy-four patients were studied during induction of anaesthesia for coronary artery bypass surgery (Table I). Twenty-five patients (Group I) received fentanyl $4.1 \mu \mathrm{g} \cdot \mathrm{kg}^{-1}$ and were ventilated with a mixture of 60 per cent nitrous oxide and 40 per cent oxygen. The remaining 49 patients received fentanyl $15 \mu \mathrm{g} \cdot \mathrm{kg}^{-1}$. Twentyseven of these patients (Group II) were ventilated with 60 per cent nitrous oxide with oxygen, whereas 22 patients received a mixture of 60 per cent nitrogen with oxygen (Group III). All patients were premedicated $1-2$ hours before operation with Opial $(10-15 \mathrm{mg})$ and atropine sulphate $0.25 \mathrm{mg}$ and received an intravenous infusion of $\mathrm{NaCl} 0.9$ per cent $(200 \mathrm{ml})$ during the period of the 
TABLE 1

Patient Data

\begin{tabular}{|c|c|c|c|}
\hline \multirow[b]{2}{*}{$\begin{array}{l}\text { Gas mixture } \\
\text { Fentanyl }\end{array}$} & Group 1 & Group II & Group III \\
\hline & $\begin{array}{c}\mathrm{N}_{2} \mathrm{O} 60 \% / \mathrm{O}_{2} 40 \% \\
4.1 \mu \mathrm{g} \cdot \mathrm{kg}^{-1}\end{array}$ & $\begin{array}{c}\mathrm{N}_{2} \mathrm{O} 60 \% / \mathrm{O}_{2} 40 \% \\
15 \mu \mathrm{g} \cdot \mathrm{kg}^{-1}\end{array}$ & $\begin{array}{c}\mathrm{N}_{2} 60 \% / \mathrm{O}_{2} 40 \% \\
15 \mu \mathrm{g} \cdot \mathrm{kg}^{-1}\end{array}$ \\
\hline $\begin{array}{l}\text { Number of patients } \\
\text { Age (years) }\end{array}$ & 25 & 27 & 22 \\
\hline range & $39-67$ & $37-66$ & $33-59$ \\
\hline median & 49 & 50 & $\$ 2$ \\
\hline Weight (kg) & $75 \pm 2$ & $75 \pm 2$ & $76 \pm 2$ \\
\hline $\begin{array}{l}\text { Number of coronary } \\
\text { by-passes per }\end{array}$ & & & \\
\hline patient & $2.6 \pm 0.3$ & $2.5 \pm 0.2$ & $2.9 \pm 0.2$ \\
\hline
\end{tabular}

study. Digitalis, diuretics and $\beta$-adrenergic blockers were withheld for at least 48 hours before operation.

\section{General Preparation}

Before the induction of anaesthesia, a 17 gauge Sorensen catheter was inserted percutaneously into the radial or brachial artery in all patients, under local anaesthesia. This catheter was used for the determination of blood pressure and for the withdrawal of arterial blood samples for determination of blood gases (ABL-2, Radiometer, Copenhagen), lactate, glucose, free fatty acid (FFA) and potassium. Another catheter was inserted in a forearm vein for the administration of drugs. Electrodes were connected for the recording of the electrocardiogram (Lead V5) and the heart rate was derived from electrocardiograph signals. In addition, a 7F Swan Ganz thermodilution catheter was guided into the pulmonary artery through the right internal jugular vein in 21 of the 74 patients (seven in each group), for cardiac output measurements and for the collection of mixed venous blood samples. Arterial and mixed venous oxygen saturations $\left(\mathrm{SO}_{2}\right)$ were determined with a reflector oximeter (American Optical Co., Bedford, Mass., U.S.A.). The haemoglobin concentration of arterial blood was measured with a Vitatron Colorimeter (Meyvis \& Co., Bergen op Zoom, The Netherlands), and oxygen content $\left(\mathrm{CO}_{2}\right)$ of the blood was calculated by the formula: $\mathrm{CO}_{2}(\mathrm{vol} \%)=\left(\mathrm{So}_{2}(\%) / 100\right) \cdot \mathrm{Hb}$ $(\mathrm{g} \%) \cdot 1.39+0.0031 \cdot \mathrm{PO}_{2}(\mathrm{mmHg})$.

For each cardiac output value (converted into cardiac index: $\left.\mathrm{CI}, 1 \cdot \mathrm{min}^{-1} \cdot \mathrm{m}^{-2}\right)$, an average of three separate measurements were made. Cardiac output in these patients was also calculated after the induction of anaesthesia by Fick's principle from oxygen uptake measured with a mass spectrometer (Perkin Elmer MGA I 100, Pomona, Calif., U.S.A.) during anaesthesia. These values correlated well with the cardiac output measured simultaneously using the thermodilution technique (Spearman rank correlation coefficient of $0.81 ; \mathrm{P}<0.001 ; n=23$ ).

\section{Biochemical Analysis}

Standards and arterial blood samples were prepared for assays as previously described. ${ }^{7.8}$ Plasma glucose and potassium were assayed with an Auto-Analyser (Technicon Instruments Corporation, Tarrytown, N.Y., U.S.A.). Lactate was determined enzymatically in deproteinized samples. ${ }^{9}$ Serum free fatty acids were measured ${ }^{10.11}$ with a Titrigraph (Radiometer, Copenhagen, Denmark).

\section{Experimental Protocol}

Baseline (control) measurements of haemodynamic and biochemical variables were obtained 15-20 minutes after the insertion of the cannulae, during the awake period. After all the baseline data had been obtained, induction of anaesthesia with fentanyl was initiated. The appropriate dose of fentanyl was administered slowly into the peripheral venous line over a period of three minutes. In addition, pancuronium bromide (Pavulon ${ }^{\otimes}$ ) $90 \mu \mathrm{g} \cdot \mathrm{kg}^{-1}$ was given to facilitate tracheal intubation and subsequent artificial ventilation with nitrous oxide (or nitrogen) with oxygen, using a servoventilator (model $900 \mathrm{~B}$, Siemens-Elema, Solna, Sweden). In the 21 patients in whom a Swan Ganz catheter was inserted, heart rate and arterial (systemic and pulmonary) pressures were measured at 5, 10 and 25 minutes after administration of fentanyl. Finally, in all patients, the haemodynamic measurements were made and arterial blood was withdrawn for 
TABLE II

Heart Rate and Arterial Pressures During Baseline (control) Period and 35 Minutes After Induction OF ANAESTHESIA

\begin{tabular}{|c|c|c|c|c|}
\hline \multirow[b]{2}{*}{$\begin{array}{c}\text { Haemodynamic } \\
\text { variable }\end{array}$} & \multirow[b]{2}{*}{$\begin{array}{l}\text { Baseline value } † \\
\qquad \mathrm{n}=74\end{array}$} & \multicolumn{3}{|c|}{$\%$ Change from baseline after induction of anaesthesia } \\
\hline & & $\begin{array}{c}\text { Fentanyl } 4.1 \mu \mathrm{g} \cdot \mathrm{kg}^{-1} \\
+\mathrm{N}_{2} \mathrm{O} / \mathrm{O}_{2} \\
\text { Group I } \\
\mathrm{n}=25\end{array}$ & $\begin{array}{c}\text { Fentanyl } 15 \mu g \cdot \mathrm{kg}^{-1} \\
+\mathrm{N}_{2} \mathrm{O} / \mathrm{O}_{2} \\
\text { Group II } \\
\mathrm{n}=27\end{array}$ & $\begin{array}{c}\text { Fentanyl } 15 \mu \mathrm{g} \cdot \mathrm{kg}^{-1} \\
+\mathrm{N}_{2} / \mathrm{O}_{2} \\
\text { Group } 11 \mathrm{I} \\
\mathrm{n}=22\end{array}$ \\
\hline $\begin{array}{l}\text { Heart rate } \\
\text { (beats } / \mathrm{min}) \\
\text { Arterial } \\
\text { pressure }(\mathrm{kPa})\end{array}$ & $71 \pm 3$ & $4 \pm 3$ & $-2 \pm 5$ & $30 \pm 5^{*}$ \\
\hline $\begin{array}{l}\text { systolic } \\
\text { diastolic } \\
\text { mean } \\
\text { pulse }\end{array}$ & $\begin{array}{r}19.2 \pm 0.4 \\
10.6 \pm 0.2 \\
13.8 \pm 0.3 \\
8.6 \pm 0.3\end{array}$ & $\begin{array}{l}-7 \pm 4 \\
-5 \pm 5 \\
-6 \pm 4 \\
-9 \pm 6\end{array}$ & $\begin{array}{r}-18 \pm 2^{*} \\
-8 \pm 3^{*} \\
-12 \pm 2^{*} \\
-30 \pm 2^{*}\end{array}$ & $\begin{aligned} 4 & \pm 4 \\
12 & \pm 4^{*} \\
7 & \pm 3^{*} \\
-3 & \pm 6\end{aligned}$ \\
\hline
\end{tabular}

†Baseline data of three groups have been combined.

* Significant $(P<0.05$, paired t-test) change from the baseline value in the corresponding patients.

biochemical analyses 35 minutes after administration of fentanyl. During this 35 -minute period no surgical stimuli were given to the patients.

Presentation of Data and Statistical Analysis

All data are presented in the text as means \pm standard error of the mean (S.E.M.). The effects of fentanyl with nitrous oxide or nitrogen with oxygen have been expressed separately in the three groups as percentage changes from the baseline value in each individual patient. However, for the sake of clarity, the baseline values of haemodynamic and biochemical variables in the three groups have been combined. The effects of the anaesthetic schedules were evaluated statistically using the two-tailed paired t-test. ${ }^{12} \mathrm{P}$ values of 0.05 or less were considered significant.

\section{RESULTS}

\section{Clinical Assessment}

During the 35-minute experimental period, electrocardiographic abnormalities (ST segment depression) were observed mainly in Group III patients. All patients underwent uneventful surgical procedures and regained consciousness within one hour after termination of anaesthesia. The use of a narcotic reversal agent or postoperative mechanical ventilation was not required in any of these patients.

\section{Arterial Blood Gas Tensions}

During ventilation, shortly after induction had been completed, there was a slight increase in $\mathrm{Pa}_{\mathrm{O}_{2}}$ and a slight decrease in $\mathrm{Pa}_{\mathrm{CO}_{2}}$ in all three groups. This resulted in a slight decrease in $\mathrm{cH}^{+}$ (increase in $\mathrm{pH}$ ). However, all blood gas values remained within the normal range during the entire experimental period: $\mathrm{cH}^{+} 44.67-35.48 \mathrm{nmol} / 1$ (pH 7.35-7.45); $\mathrm{PCO}_{2} 4.7-6.0 \mathrm{kPa} \quad(35-45$ $\mathrm{mmHg}) ; \mathrm{PO}_{2} 12-20 \mathrm{kPa}(90-150 \mathrm{mmHg})$.

\section{Haemodynamic Changes}

The effect of induction of anaesthesia by fentanyl (with or without nitrous oxide) on the heart rate and blood pressure is shown in Table II. While the heart rate remained unchanged in Groups I and II, fentanyl 4.1 and $15 \mu \mathrm{g} \cdot \mathrm{kg}^{-1}$ with nitrous oxide and oxygen, it was increased in the patients belonging to Group III, fentanyl $15 \mu \mathrm{g} \cdot \mathrm{kg}^{-1}$ with nitrogen and oxygen. The mean arterial pressure decreased from its baseline value in Group II ( 12 per cent), mainly due to a fall in systolic pressure ( 18 per cent), since the diastolic pressure dropped by only 8 per cent. In Group 111, mean (7 per cent) and diastolic (12 per cent) pressures increased significantly, while no changes were observed in Group I patients.

A more extensive examination of the haemodynamic variables was carried out in 21 patients (seven in each group). Apart from the measurements of ventricular haemodynamic data and heart rate, systemic and pulmonary arterial pressures were also recorded at intervals of 5,10 and 25 minutes after administration of fentanyl. While no major changes were observed in the patients of Group II, heart rate did increase in Groups I and III. The rate returned to control (baseline) values after 10-25 minutes in Group I, but remained at a higher level in Group III pa- 
TABLE III

Haemodynamic and Respiratory Data Before and After Induction of Anaesthesia in 21 Patients ( 7 in each group)

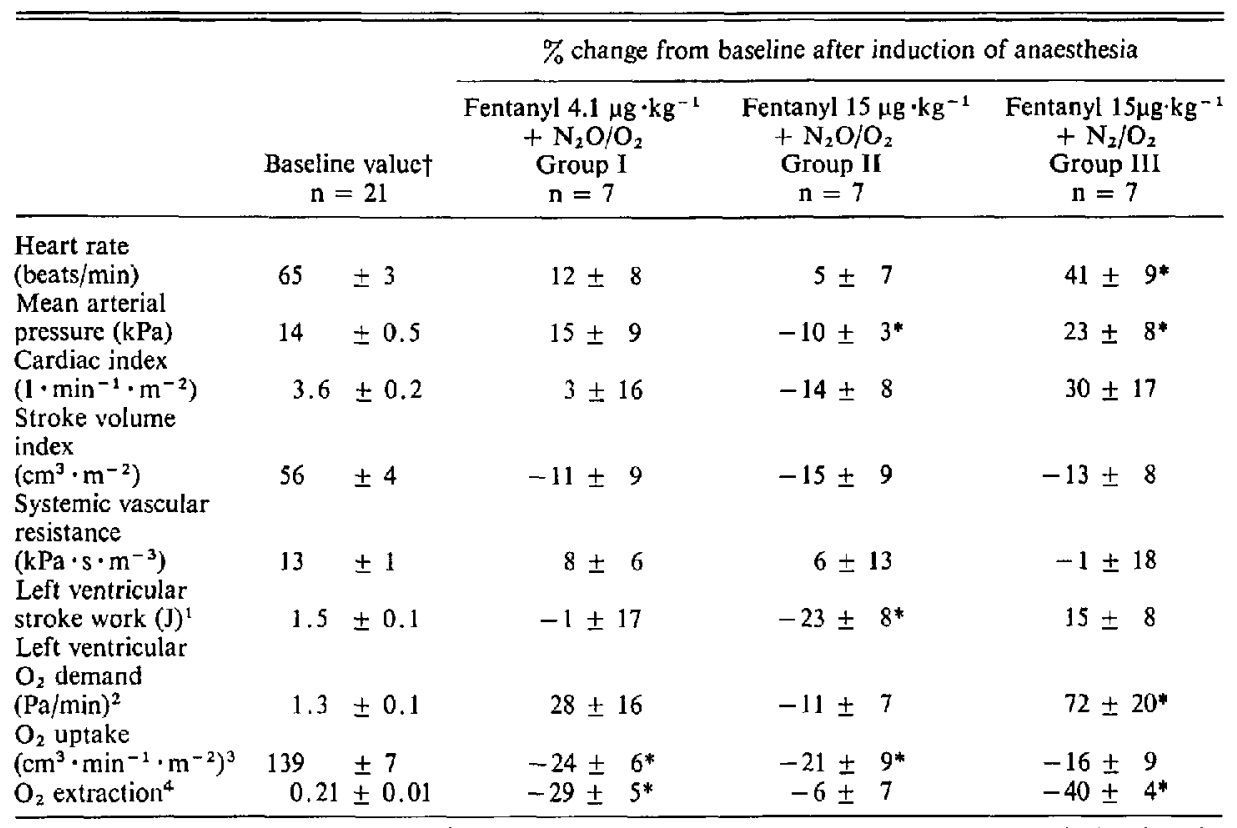

1, Calculated as: stroke volume $\left(\mathrm{cm}^{3}\right) \times$ Mean arterial pressure $(\mathrm{mmHg}) \times 0.00014 .2$, Calculated as the double product: systolic artery pressure $\times$ heart rate. 3 , Total body $\mathrm{O}_{2}$ uptake $=$ cardiac index $\times\left(\mathrm{C}_{\mathrm{O}_{2}}\right.$ art $\mathrm{C}_{\mathrm{O}_{2}}$ ) mixed venous). 4 , Defined as $\left(\mathrm{C}_{\mathrm{O}_{2}}\right.$ art $-\mathrm{C}_{\mathrm{O}_{2}}$ mixed venous)/ $\mathrm{C}_{\mathrm{O}_{2}}$ art.

tBaseline data of the three groups have been combined.

*Significant $(P<0.05$, paired $t$-test) change from the baseline value in the corresponding patients.

tients. In each group the systemic arterial pressure increased slightly immediately after the tracheal intubation $(t=5 \mathrm{~min})$ and then returned to baseline values in Group I, decreased below the baseline value in Group II and increased further in Group III patients. The pulmonary arterial pressure changed little in the first two groups but was slightly elevated at all measurement periods in the last group. Table III shows a number of haemodynamic and respiratory variables before and 35 minutes after induction of anaesthesia. Opposite effects on cardiovascular function were observed in the patients who received fentanyl $15 \mu \mathrm{g} \cdot \mathrm{kg}^{-1}$ when nitrous oxide was replaced by nitrogen (compare Group II and III). This was most pronounced in the mean arterial blood pressure and cardiac index, which showed a decrease of $10-14$ per cent in Group II and an increase of 23-30 per cent in Group III. The decrease in cardiac index and left ventricular stroke work in Group II did not result in impaired oxygen supply, since total body oxygen extraction did not change (Table III). On the other hand, oxygen extraction decreased by 40 per cent $(\mathrm{P}<0.001)$ compared to the awake value in Group III. In addition, there was a marked increase in myocardial oxygen demand calculated as double product systolic arterial pressure $x$ heart rate. When the lower dose of fentanyl (Group I) was administered in combination with nitrous oxide no significant haemodynamic changes were seen (Table II). However, there was a remarkable decrease in total body oxygen uptake and extraction.

\section{Biochemical Changes}

The effects of the different anaesthetic schedules on the biochemical variables are shown in Table IV. It is to be noted that the glucose values in the control period are relatively high but are comparable to those reported by others in patients with coronary heart disease. ${ }^{8,13,14}$ Several factors may have contributed to the increased level of glucose in our patients. For example, total opium alkaloid (Opial), given in the pre-anaesthetic phase, contains 66 percent 
TABLE IV

Biochemical Variables Before and After Anaesthesia With Fentanyl

\begin{tabular}{|c|c|c|c|c|}
\hline \multirow[b]{2}{*}{$\begin{array}{c}\text { Biochemical } \\
\text { variables }\end{array}$} & \multirow[b]{2}{*}{$\begin{array}{c}\text { Baseline value } \\
\text { mol } \cdot \mathrm{m}^{-3} \\
n=52\end{array}$} & \multicolumn{3}{|c|}{$\%$ change from baseline after induction of anaesthesia } \\
\hline & & $\begin{array}{c}\text { Fentanyl } 4.1 \mu \mathrm{g} \cdot \mathrm{kg}^{-1} \\
+\mathrm{N}_{2} \mathrm{O} / \mathrm{O}_{2} \\
\text { Group I } \\
\Omega=18\end{array}$ & $\begin{array}{c}\text { Fentanyl } 15 \mu \mathrm{g} \cdot \mathrm{kg}^{-1} \\
+\mathrm{N}_{2} \mathrm{O} / \mathrm{O}_{2} \\
\text { Group II } \\
n=19\end{array}$ & $\begin{array}{c}\text { Fentanyl } 15 \mu \mathrm{g} \cdot \mathrm{kg}^{-1} \\
+\mathrm{N}_{2} / \mathrm{O}_{2} \\
\text { Group III } \\
n=15\end{array}$ \\
\hline Lactate & $0.41 \pm 0.02$ & $45 \pm 11^{*}$ & $-4 \pm 5$ & $118 \pm 34^{*}$ \\
\hline FFA & $1.06 \pm 0.05$ & $20 \pm 11$ & $-1 \pm 4$ & $40 \pm 8^{*}$ \\
\hline Glucose & $6.7 \pm 0.2$ & $22 \pm 7^{*}$ & $1 \pm 2$ & $23 \pm 6^{*}$ \\
\hline Potassium & $4.3 \pm 0.1$ & $-3 \pm 2$ & $-5 \pm 1^{*}$ & $-9 \pm 2^{*}$ \\
\hline
\end{tabular}

†Baseline data of the three groups have been combined.

*Significant $(P<0.05$, paired $t$-test) change from baseline value in the corresponding patients.

morphine, which raises the blood glucose level. ${ }^{15.16}$ Similarly, withdrawal of betablockers ${ }^{17}$ and stress ${ }^{18.19}$ before operation may also increase blood glucose levels.

Increases in arterial lactate ( 118 per cent), free fatty acids (40 per cent) and glucose (23 per cent) were found in the patients of Group III (the group without nitrous oxide), whereas no such changes could be detected in patients of Group II (Table IV). However, with the low dose of fentanyl in combination with oxygen and nitrous oxide (Group I) a significant increase in lactate and glucose was again seen, without significant changes in the free fatty acid level. A small decrease in arterial serum potassium concentration was found in Groups II and III (Table IV).

\section{Discussion}

A naesthetic agents may have diverse effects on metabolic and hormonal activity. One group of drugs (e.g. halothane) may increase the blood levels of glucose, cortisol and lactate ${ }^{20}$ while decreasing levels of catecholamines. ${ }^{21}$ Other agents, such as fentanyl, may increase the activity of the adrenergic system, thereby causing enhanced excretion of catecholamines in urine ${ }^{22}$ and, presumably, increased concentration in the blood as well. Since an increase in sympathetic activity potentially could lead to serious complications during anaesthesia in patients undergoing surgery for ischaemic heart disease, a knowledge of the haemodynamic and biochemical effects of the anaesthetic regimes used is particularly essential.

When fentanyl $15 \mu \mathrm{g} \cdot \mathrm{kg}^{-1}$ was administered to patients without nitrous oxide (Group III), both haemodynamic and biochemical effects, consisting of tachycardia, hypertension, enhanced left ventriculat oxygen demand and elevated blood levels of lactate, free fatty acids and glucose, indicate an increase in sympathetic nervous system activity probably due to "unbalanced" anaesthesia. A lower dose of fentanyl $\left(4.1 \mu \mathrm{g} \cdot \mathrm{kg}^{-1}\right)$ given with nitrous oxide (Group I) had no haemodynamic effects but produced biochemical changes similar to those in Group III. However, when the patients were given fentanyl $15 \mu \mathrm{g} \cdot \mathrm{kg}^{-1}$ together with nitrous oxide (Group II), no changes in the blood levels of lactate, free fatty acids and glucose occurred and the blood pressure fell only moderately. The slight decrease in cardiac index in Group II appears to have been due to the addition of nitrous oxide, since the cardiac index tended to increase in Group III in which the same dose of fentanyl was given without nitrous oxide. The changes in the left ventricular work paralleled those in the cardiac index and, despite the slight decrease in cardiac index in Group II, overall oxygen supply was adequate because total body extraction remained unchanged after the administration of fentanyl $15 \mu \mathrm{g} \cdot \mathrm{kg}^{-1}$ in combination with the inhaled nitrous oxide and oxygen mixture.

The decrease in the total body oxygen uptake in all three groups of patients was apparently secondary to a diminution of the metabolic rate during the anaesthetic state resulting from fentanyl and nitrous oxide. ${ }^{23.24}$ Group III patients, in whom the myocardial oxygen demand increased (as suggested by the changes in the heart rate, cardiac output and blood pressure) exhibited a reduction in total oxygen uptake probably for two reasons. First, in the patients with coronary artery disease, increased myocardial oxygen demand may not have been accompanied by an adequate increase in oxygen supply, thus leading to myocardial ischaemia. A retrospective examination of the available electrocardiographic 
records confirmed that 9 out of 11 patients in Group III exhibited ischaemic electrocardiogram changes (ST depression) in the 35-minute observation period. One out of three in Group I and only two of 17 patients in Group II showed these changes in the corresponding period. The second and perhaps more important reason for the decrease in total body oxygen uptake in the presence of a possible increase in myocardial oxygen consumption $\left(\mathrm{MVO}_{2}\right)$ is that the latter $\left(\mathrm{MVO}_{2}\right.$ changes) would be dissipated by the former (total body oxygen uptake changes) since, normally, the heart consumes only $8-10$ per cent $(20-25$ $\left.\mathrm{ml} / \mathrm{min}^{-1}\right)^{26}$ of the amount of oxygen used by the body. The marked decrease ( 40 per cent) in oxygen extraction in Group III patients was apparently due to reduced total body oxygen uptake coupled with a high cardiac output.

The data reported in the present investigation suggest that, from both haemodynamic and biochemical viewpoints, a combination of fentanyl $15 \mu \mathrm{g} \cdot \mathrm{kg}^{-1}$ and nitrous oxide with oxygen provides adequate and "balanced" anaesthesia, while, at the same time, this anaesthetic regimen significantly reduces any tendency to increased left ventricular work. This combination also maintains an adequate oxygen supply and provides a satisfactory coronary artery perfusion pressure. These cardiovascular effects may well be beneficial for the patients undergoing coronary artery surgery during which a stress-free induction of anaesthesia is so essential. Moreover, the lack of a rise in free fatty acids indicates the absence of a further potential hazard for these patients.

Recently, Stanley and coworkers ${ }^{3,4}$ have demonstrated that large doses of fentanyl $\left(50-100 \mu \mathrm{g} \cdot \mathrm{kg}^{-1}\right)$ can be used as the sole anaesthetic without deleterious cardiovascular changes in patients with coronary artery disease. When such doses were used in combination with nitrous oxide in female patients undergoing tubal surgery, no abnormal metabolic and hormonal responses were seen but apnoea requiring urgent ventilation and administration of naloxone was encountered in a few cases. ${ }^{20}$ It seems that larger doses of fentanyl $\left(50-100 \mu \mathrm{g} \cdot \mathrm{kg}^{-1}\right)$ could also be used safely in cardiac surgery, but one has to be on the lookout for potential respiratory hazards, particularly when these doses are used in conjunction with another anaesthetic agent.

Finally, we ought to focus attention on some limitations of our study, which was carried out during routine surgery. All patients received premedication about 1.5 hours before transpor- tation to the surgical theatre and the patients had tracheal intubation and received pancuronium to facilitate intubation. Although pancuronium may have interfered with the changes in heart rate ${ }^{27,28}$ and blood $\mathrm{K}^{+}$levels, ${ }^{29}$ our study does provide adequate information for a clinical setting.

\section{ACKNOWLEDGEMENTS}

The authors are grateful to Mariys Stewart, Wout Breeman, Jaap Deckers, M.Sc. for expert technical assistance. We also thank all nurses in the anaesthetic and post-operative unit for their cooperation and Louise van Solkema for her assistance in the preparation of the manuscript.

J.W. de Jong is an established investigator for the Dutch Heart Foundation, which supported part of this study.

\section{REFERENCES}

1. De Castro, J. Neuroleptanalgésie et système adrenergique, Ars Med. 1:69(1970).

2. FREYE, E. Cardiovascular effects of high dosages of fentanyl, meperidine and naxolone in dogs. Anaesth. Analg. Curr. Res. 53: 40 (1974).

3. Lunn. J.K., Webster. L., STAnley, T.H. EISELE, J. \& WoODWARD, A. Fentanyl blood levels during high dose fentanyl anesthesia in man: Correlation with cardiovascular effects. Abstract Amer. Soc. Anesth. Ann. Meeting. p. 583 (1978).

4. Stanley, T.H., Philain, D.M. \& Coggins, C. H. Fentanyl oxygen anaesthesia for coronary artery surgery: cardiovascular and antidiuretic hormone response, Canad. Anaesth. Soc. J. 26: 168 (1978).

5. Verdouw, P.D., de Jong, J.W., Merin, R.G. \& SchamhardT, H.C. Influence of different anesthetics on myocardial performance and metabolism. J. Mol. Cell. Cardiol. Supp. 9:60(1977)

6. Simonson. S. \& Kiekshus, J.K. The effect of free fatty acids on myocardial oxygen consumption during atrial pacing and catecholamine infusion in man. Circulation S8: 484 (1978).

7. De Jong, J.W., Verdouw, P.D. \& Remme, W.J. Myocardial nucleoside and carbohydrate metabolism and hemodynamics during partial occlusion and reperfusion of pig coronary artery. J. Mol. Cell. Cardiol. 9: 297 (1977).

8. Remme, W.J., de Jong, J.W. \& Verdouw, P.D. Effects of pacing-induced myocardial ischemia on hypoxanthine effux from the human heart. Am. J. Cardiol. 40:55 (1977).

9. Apstein, C.S., Puchner, E. \& Brachfield, N Improved automated lactate determination. Anal. Biochem. 38: 20(1970).

10. DOLE, V.P. \& MEINERTZ, H. Microdetermination of long-chain fatty acids in plasma and tissues. $J$. Biol. Chem. 235: 2595 (1960).

11. Trout, D. L., Estes, E.H. Jr. \& Friedrerg, S.J. Titration of free fatty acids in plasma. A study of current methods and a new modification. J. Lipid Res. I: 199 (1960). 
12. Colton, T.H. Statistics in Medicine. Boston: Little, Brown Co. (1974).

13. Most. A.S., Gorlin. R. \& Soeldner, J.S. Glucose extraction by the human myocardium during pacing stress. Circulation 45:92 (1972).

14. Inoue, S., Ohta, M., Iizuka, T. \& Mura, S. Glucose tolerance, serum insulin and lipid abnormalities in patients with coronary heart disease. Jap. Heart J. 16: 670 (1975).

15. VASSAle, $M$. Role of catecholamine release in morphine hyperglycemia. Amer. J. Physiol. 200: $530(1961)$

16. Borison, H.L., Fishburn, B.R., Bhide, N.K. \& MCCARThY, L.E. Morphine-induced hyperglycaemia in the cat. J. Pharmacol. Exp. Ther. 138: 229 (1962).

17. Abramson, E.A. \& WoEber, K.A. Effects of propranolol on the hormonal and metabolic responses to insulin-induced hypoglycaemia. Lancet 2: $1386(1966)$

18. Taggart, P. \& Carruthers, M. Suppression by oxprenolol of adrenergic response to stress. Lancet 2: 256 (1972).

19. Taggart, P., Carruthers, M. \& Somerville, W. Electrocardiogram, plasma catecholamines and lipids, and their modification by oxprenolol when speaking before an audience. Lancet $2: 341$ (1973).

20. Hall, G.M., Young, C.. Holdcroft, A. \& ALAGHBAND-ZADEH, J. Substrate mobilisation during surgery. A comparison between halothane and fentanyl anaesthesia. Anaesthesia 33: 606 (1978).

21. RoIzen, M.F., Moss, J., Henry, D.P. \& Kopin, I.J. Effects of halothane on plasma catecholamines. Anesthesiology 41: 432(1974).
22. Liu, W.S., Bidwal, A.V., Lunn, J.K. \& StanI.EY, T.H. Urine catecholamine excretion after large doses of fentanyl, fentanyl and diazepam and fentanyl, diazepam and pancuronium. Canad. Anaesth. Soc. J. 24:371 (1977).

23. WESTENSKOW, D.R. \& JoRdAN, W.S. Changes in oxygen consumption induced by fentanyl and thiopentone during balanced anaesthesia. Canad. Anaesth. Soc. J. 25: 18 (1978).

24. Brismar, B., Bergenwald, L., Cronestrand, R., JorfeldT, L. \& JUhlin-DANNFELdT, A. The cardiovascular effects of ncuroleptanacsthesia. Acta Anaesth. Scand. 21: 100(1977)

25. Schmidt, D.H., Weis, M.B. Casarella, W.J. Fowler, D.L., Sciacca, R.R. \& Cannon, P.J. Regional myocardial perfusion during atrial pacing in patients with coronary artery disease. Circulation 53: 807 (1976).

26. Gibis, C.L. \& Chapman, J.B. Cardiac energetics. In: The Handbook of Physiology, section 2. The cardiovascular system, vol. I. The Heart (eds. R.M. Berne, N. Sperdakis \& S.R. Geiger) American Physiological Society, Bethesda, p. 775 (1979).

27. Saxena, P.R. \& Bonta, I.L. Mechanism of selective cardiac vagolytic action of pancuronium bromide. Specific blockade of cardiac muscarinic receptors. Europ. J. Pharmacol. 1/: 332 (1970).

28. SAXENA, P.R. \& BoNTA, I.L. Specific blockade of cardiac muscarinic receptors by pancuronium bromide. Arch. Int. Pharmacodyn. 189:410(1971).

29. KONCHIGERI, H.N. \& TAY, C. H. Influence of pancuronium on potassium efflux produced by succinylcholine. Anesth. Analg. Curr. Res. 55: 474 (1976).

\section{RÉSUMÉ}

Les auteurs ont comparé les modifications de paramètres hémodynamiques et biologiques amenées par trois techniques d'induction d'anesthésie dans des cas de pontages aortocoronariens. Les patients d'un premier groupe ont reçu une dose de $4.1 \mu \mathrm{g} \cdot \mathrm{kg}^{-1}$ de fentanyl et ont été ventilés avec un mélange de protoxyde d'azote et d'oxygène dans des proportions de 60 et de 40 pour cent; ceux d'un second groupe recevaient $15 \mu \mathrm{g} \cdot \mathrm{kg}^{-1}$ de fentanyl avec le même mélange de protoxyde; enfin, dans un troisième cas, une dose de $15 \mu \mathrm{g} \cdot \mathrm{kg}^{-1}$ était administrée et les patients étaient ventilés avec un mélange d'azote et d'oxygène dans un rapport $60 / 40$. Le fentanyl à la dose de $15 \mu \mathrm{g} \cdot \mathrm{kg}^{-1}$ avec une ventilation au protoxyde d'azote amenait une diminution simultanée de la consommation d'oxygène, de l'index cardiaque, du travail d'éjection ventriculaire gauche avec extraction d'oxygène diminuée. La pression diastolique (témoin de la perfusion coronarienne) n'était que peu diminuée et l'on n'a pas observé de modification des lactates, du glucose et des acides gras libres artériels. Les doses inférieures de fentanyl avec le protoxyde n'amenaient pas de modifications hémodynamiques mais diminuaient la consommation et l'extraction d'ox ygène.

D'autre part, les patients qui ont reçu les doses de $15 \mu \mathrm{g} \cdot \mathrm{kg}^{-1}$ de fentanyl avec une ventilation à l'azote-oxygène, ont présenté des élévations de la fréquence cardiaque. de la pression artérielle, de l'index cardiaque et du travail d'éjection ventriculaire gauche en même temps qu'une diminution significative de l'extraction d'oxygène.

Chez les malades ayant reçu $4.1 \mu \mathrm{g} \cdot \mathrm{kg}^{-1}$ de fentanyl avec protoxyde, ainsi que chez ceux ayant reçu $15 \mu \mathrm{g} \cdot \mathrm{kg}^{-1}$ avec le mélange azote-oxygène, on a trouvé des augmentations significatives des lactates, du glucose et des acides gras libres, témoin d'une augmentation de l'activité sympathique.

Nous concluons que le fentanyl à la dose de $15 \mu \mathrm{g} \cdot \mathrm{kg}^{-1}$ associé à une ventilation avec un mélange de 60 pour cent de protoxyde d'azote et d'oxygène, produit une induction satisfaisante au point de vue hémodynamique et biochimique chez les coronariens. 